\title{
血液浄化用バルーン付きダブルルーメンカテーテルのバルーン 至適注入量
}

\author{
長谷川義治＼cjkstart高橋 伸二 河村 文夫 \\ 済生会宇都宮病院集中治療室（～321-0974 杤木県宇都宮市竹林町 \\ 911-1)
}

Key words: (1) blood access, (2) occlusion balloon, (3) hemodiafiltration

血液浄化のブラッドアクセスとして，バルーン付き ダブルルーメンカテーテル (B-DLC)が開発された。従 来のダブルルーメンカテーテルに比べて血管壁にへば りつき現象1)がなく, 静脈還流を遮断し脱血が良好に行 えることが利点とされ, 循環動態が良好でない症例の 血液透析 (HD) や, 持続血液濾過透析 (CHDF) に推 奨されている。しかし, 我々はB-DLCバルーンの貼付 文書に拉いて推奨されている注入量範囲内で拡張した にもかかわらず，挿入側下肢に静脈還流の完全遮断が 原因と思われる著明な浮腫を生じた症例を経験した。 推奨されている注入量 $1.0 \sim 2.0 \mathrm{ml}$ に問題があるので はないかと考え, 静脈還流程度の観察から至適注入量 を検討した。

\section{対象亡方法}

対象は急性腎不全のため CHDF, HD を必要とした 2 症例である。第 1 例は 63 歳, 男性 $(50 \mathrm{~kg}, 171 \mathrm{~cm})$ で肝細胞癌の手術後肝不全および腎不全となり血漿交 換と同時に CHDF，HD を導入した。第 2 例は 48 歳, 男性 $(63 \mathrm{~kg}, 172 \mathrm{~cm})$ で意識障害, 重症肺炎, 急性 腎不全のため当院に搬送され, CHDF, HDを導入した。 両症例ともB-DLCは大腿静脈に挿入留置した。バルー ンは造影剂（300オムニパーク原液）で拡張した。注入 量は最初 $2.0 \mathrm{~m} l$ とし, $1.5 \mathrm{ml}, 1.0 \mathrm{ml}, 0.9 \mathrm{ml}, 0.8 \mathrm{ml}$ と漸減し, それぞれで拡張したバルーン径を測定し, 希 釈造影剂（生理食塩水による 10 倍希釈液 $10 \mathrm{ml}$ ）を脱
血孔から注入し，静脈還流の程度を確認した。観察は X線透視下に行い, 必要に応じてフィルムに撮影した。 また，被曝線量が最少になるよう心がけ，検討に先立 ち患者あるいは家族から検討の目的を説明し，口頭で 同意を得た。

\section{結果}

注入量と実測したバルーン径の関係を Table 1 に示 した。第 1 例ではバルーンは総腸骨静脈に留置されて おり, 静脈還流は注入量 $1.0 \mathrm{~m} l$ で完全に遮断され内腸 骨静脈へシフトした (Fig. 1a)。そして $0.8 \mathrm{ml}$ で遮断 は解除された (Fig. 1b)。第2例ではバルーンは外腸骨 静脈に留置されており， $0.9 \mathrm{~m} l$ で血流遮断が解除され た。

\section{考察}

B-DLCはバルーンの拡張によって静脈還流が長時間 にわたって遮断されると，下肢の浮腫や静脈血栓を形 成する危険性がある。今回の検討から明らかになった ことは，(1)日本人男性の標準的な体格の症例において も B-DLCバルーンは外腸骨静脈に留置されたこと, (2)

Table 1 Volume-diameter relationship of the balloon

\begin{tabular}{lcccc}
\hline \hline Volume $(\mathrm{m} l)$ & 0.5 & 1.0 & 1.5 & 2.0 \\
\hline Diameter $(\mathrm{mm})$ & 10 & 12.5 & 15 & 17 \\
\hline
\end{tabular}

Optimal inflation volume for an occlusion balloon of a double-lumen vascular access catheter

Yoshiharu Hasegawa, Shinji Takahashi, Fumio Kawamura

Intensive Care Unit, Saiseikai Utsunomiya Hospital (911-1 Takebayasi, Utsunomiya 321-0974, Japan)

J Jpn Soc Intensive Care Med 2001; 8: 133 134 


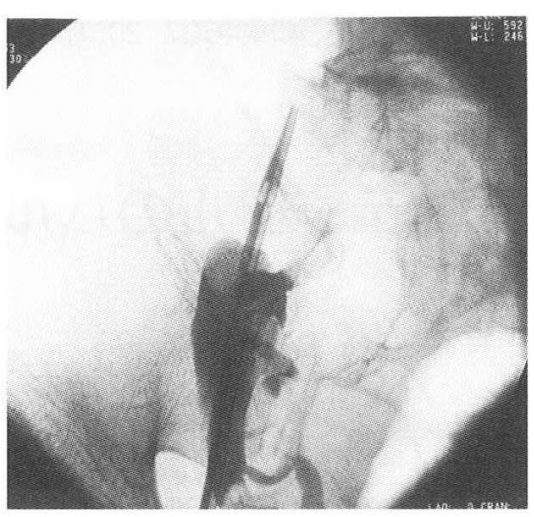

a

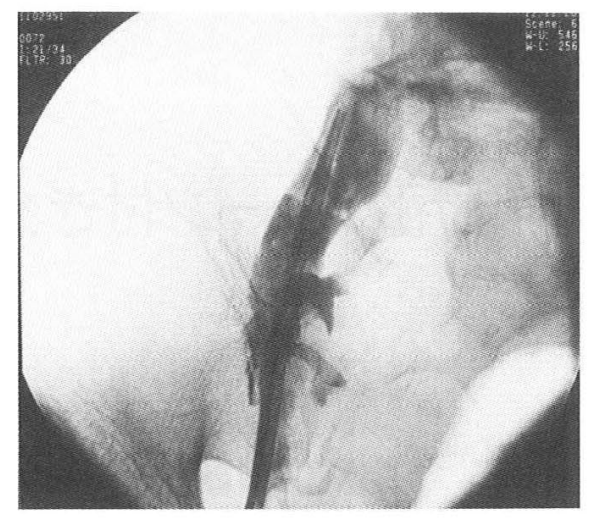

b

Fig. 1 Common iliac venography.

a. Inflated to $1.0 \mathrm{ml}$, the balloon occluded the common iliac vein with bypass flow to the internal iliac vein. b. Deflated to $0.8 \mathrm{ml}$, the common iliac vein was released.

バルーンが総腸骨静脈に留置されていても $1.0 \mathrm{ml}$ 注入 で完全に静脈還流が遮断されたこと，そして(3)バルー ンが外腸骨静脈に留置されている可能性も考慮して, 静脈還流の完全遮断が起こらない $0.8 \mathrm{ml}$ が至適注入量 と考えられたことである。貼付文書で推奨されている 注入量は $1.0 \sim 2.0 \mathrm{~m} l$ である。今回の測定では $1.0 \mathrm{~m} l$ 注人するとバルーン径は約 $12.5 \mathrm{~mm}$ であり, 血流遮断 が解除されたときのバルーン径は $12.3 \mathrm{~mm}, 11.9 \mathrm{~mm}$ であった。この結果は推奨されている注入量が過量で あることを示している。妻谷ら 2゙は, 下大静脈内径が循 環血液量によってかなり変化し, 特に糖尿病症例では不 安定になりがちであるとしている。また, Koomanら は, 高血圧を有する透析患者は, 静脈のコンプライア ンスが減少していると示唆している。実際, ICU 入室 患者は低アルブミン血症, 貧血, 発熱などで血管内脱 水の傾向があるため，またカテコラミンなどにより血 管が収縮していることが多い。したがって，血管が十 分に拡張している患者を対象に検討されたと思われる B-DLCの至適注入量 $1.0 \sim 2.0 \mathrm{ml}$ は, ICU 管理が必要 な重症患者では過量になるものと考えられる。

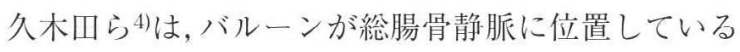
場合,バルーンを拡張すると静脈血流が遮断されるが, 内腸骨静脈を経て刘側の総腸骨静脈に流入するので下
肢浮腫や静脈血栓は起こりにくく, しかも, 総腸骨静脈 でバルーンを拡張すれば,へばりつき現象の回避のみな らず, 血流不足となりやすい症例には组流確保の意味で も有用であり,さらに再循環率も0\%となる利点がある と報告している。B-DLCの挿人可能な長さは $20 \mathrm{~cm}$ で あるが, 刺入部位や刺入の深さによってはバルーンが外 腸骨静脈に留置される可能性がある。長時間留置が必 要なCHDFでは, 完全遮断を避けるために脱血側から 少量の希釈造影剂を注入し，血流遮断の有無を確認す ることが安全確保に重要と考えられた。

本論文の要旨は, 第8回日本集中治療医学会関束甲信越地) 会（1999 年，東京）に扔いて発表した。

$$
\text { 文献 }
$$

1) 天野 泉.テンポラリーブラッドアクセス. 臨床透析 1996; 12: 87180.

2) 青谷憲一, 穴川元信, 不田悦弘, 他. 維持血液透析患省における下 大静脈径変化の検討. 透析会誌 1999; 32: 205-10.

3) Kooman JP, Wijnen JAG, Draaijer P, et al. Compliance and reactivity of the peripheral venous system in chronic intermittent hemodialysis. Kidney Int 1992; 41: 1041-8.

4) 久小田和丘, 小川内誠, 穴原満夫, 他. IIII液透析用バルーン付き夕 ブルルーメンカテーテルの長所と短所. 人丁葴器 1998; 27: 202-5.

受付 12000 年 3 月 2 H 採択H 2000 年. 12 月 $27 \mathrm{H}$ 